\title{
COMMENTS
}

\section{Limits on the Privity and Assignment of Legal Malpractice Claims}

\author{
Tom W. Bell†
}

An assault on privity has swept through much of tort law in the United States, freeing plaintiffs to press charges of negligence against even those with whom they have never had contractual relations. With the exception of scattered pockets of resistance, this movement has revolutionized the field of legal malpractice. Following California's lead, many state courts no longer consider lack of privity a bar to a party who has suffered the effects of an attorney's malpractice. ${ }^{1}$ At the same time, these courts have almost universally resisted another policy that would also free more parties to press legal malpractice claims: allowing the clients of negligent attorneys to assign their claims to third parties. ${ }^{2}$ Here, too, California courts lead the way.

Courts have lowered the privity bar in order to open new routes to the litigation of legal malpractice claims. In particular, courts have relaxed privity requirements in order to advance three

$\dagger$ B.A. 1987, University of Kansas; M.A. 1989, University of Southern California; J.D. Candidate 1993, The University of Chicago.

2 California's multi-factored balancing test of attorney liability to parties not in privity frst appeared in Biakanja v Irving, 49 Cal 2d 647, 320 P2d 16, 19 (1958), and was subsequently modified in Lucas v Hamm, 56 Cal 2d 583, 15 Cal Rptr 821, 364 P2d 685, 687-88 (1961). For an analysis of the widespread influence of these cases, see Ronald $E$. Mallen and Jeffrey M. Smith, 1 Legal Malpractice § 7.11 at 383-84 (West, 3d ed 1989).

' See, for example, Goodley v Wank \&' Wank, Inc., 62 Cal App 3d 389, 133 Cal Rptr 83 (1976) (cause of action for legal malpractice claim held not assignable); Continental Casualty Co. $v$ Pullman, Comley, Bradley \& Reeves, 709 F Supp 44, 50 n 7 (D Conn 1989) (citing a collection of cases holding claims for legal malpractice not assignable). 
policy goals: providing remedies to victims of legal malpractice, forcing negligent attorneys to bear the costs of their behavior, and deterring further legal malpractice. Allowing claims to be assigned would achieve similar results. It would encourage the development of a market in legal malpractice claims, a market where victims could find immediate redress and negligent attorneys would face efficient enforcement mechanisms. But although the threat of being sued for legal malpractice haunts the thoughts of practicing attorneys (or perhaps because it does), the positive aspects of allowing their assignment have not yet received serious consideration. $^{3}$ This Comment discusses whether arguments supporting the abandonment of the privity requirement in legal malpractice claims weigh in favor of allowing the assignment of such claims. ${ }^{4}$

Section I of the Comment describes how and why courts have almost universally lowered the privity bar to legal malpractice claims. Section II discusses the reluctance of courts to relax restrictions on the assignment of such claims. Section III shows how the policies driving these two trends in the case law-lowering the privity bar but forbidding assignment-are at odds with one another. Section IV squares the arguments for disallowing assignment with arguments for easing the privity requirement. It then measures both trends against the policies of providing equitable relief, apprehending malpracticing attorneys, deterring negligence, protecting attorney-client relations, and protecting the legal system from being overburdened. The Comment concludes that the interests of consistency and public policy favor permitting vol-

\footnotetext{
3 Although several researchers have argued on behalf of the assignability of tort claims in general, none of them have addressed legal malpractice claims in particular or compared the effects of relaxing privity with allowing assignability. See, for example, Robert Cooter, Towards a Market in Unmatured Tort Claims, 75 Va L Rev 383 (1989) (developing a model of a market for tort claims); Marc J. Shukaitis, A Market in Personal Injury Tort Claims, $16 \mathrm{~J}$ Legal Stud 329 (1987) (outlining significant advantages that a market in personal injury tort claims would offer to victims); Geoffrey P. Miller, Some Agency Problems in Settlement, $16 \mathrm{~J}$ Legal Stud 189, 196-97 (1987) (arguing agency costs for settlement would largely disappear if client could sell claim to attorney); Charles J. Goetz, Law and Economics 39-43 (West, 1984) (discussing economic advantages of allowing personal tort claims to be assigned); Harold R. Weinberg, Tort Claims as Intangible Property: An Exploration from an Assignee's Perspective, $64 \mathrm{Ky} \mathrm{L} \mathrm{J} 49$ (1975) (criticizing legal doctrines that disallow assignment of personal tort claims).

4 The common law initially forbade the assignment of all choses in action. Courts gradually eroded this rule, however, and allowed assignment of actions that survived the death of the plaintiff. Weinberg, $64 \mathrm{Ky} \mathrm{L} \mathrm{J}$ at 51-74 (cited in note 3). Some states have codified this doctrine in statutes that allow most causes of action to be assigned-but not those arising out of personal torts. See, for example, Cal Civ Code § 954 (West 1992); NY Gen Oblig Law § 13-101 (McKinney 1992). Courts have relied on this distinction to deny that legal malpractice claims can be assigned. See Section IV.B.2.
} 
untary assignments of legal malpractice claims while forbidding involuntary (as opposed to both voluntary and nonvoluntary ${ }^{5}$ ) assignments that violate clients' rights to confidential relations with their attorneys.

\section{The Assault on Privity}

The common law rule of strict privity once barred plaintiffs from suing in tort on any claim arising outside of a contractual relation. A sustained assault has weakened this rule, however, and now many state courts allow parties not in privity to sue in tort on legal malpractice claims. ${ }^{6}$ Courts have generally justified the current view by arguing that it provides remedies to victims of legal malpractice, places losses on the responsible attorneys, and deters culpable behavior. ${ }^{7}$

Although a few states still resist the trend toward relaxing the privity rule for legal malpractice claims, "the vast majority of modern decisions have favored expanding privity beyond the confines of the attorney-client relationship." 8 State courts now use a variety of standards for determining attorneys' liability to non-clients. California's multi-factor balancing test, developed in the seminal cases of Biakanja $v$ Irving ${ }^{9}$ and Lucas $v$ Hamm, ${ }^{10}$ has met with widespread favor. ${ }^{11}$ California courts have also generated an alternative (and potentially conflicting) standard for legal malpractice liability by extracting just one element from the multi-factor test - foreseeability of harm. ${ }^{12}$ This standard, however, has found little

See text accompanying notes $145-48$.

- See, for example, Lucas, 364 P2d at 687-88; Norman v Brown, Todd \& Heyburn, 693 F Supp 1259 (D Mass 1988). Unlike assignability, the privity of legal malpractice claims has drawn a fair amount of attention from legal scholars. For the most recent work on this topic, see Jack I. Samet, et al, The Attack on the Citadel of Privity, 20 The Brief 9 (Winter 1991). See also Mallen and Smith, 1 Legal Malpractice ch 7 at 360-400 \& 1991 Supp (cited in note 1).

7 See, for example, Auric v Continental Casualty Co., 111 Wis 2d 507, 331 NW2d 325, 328-29 (1983); Licata v Spector, 26 Conn Supp 378, 225 A2d 28, 30 (Ct Comm PI 1966); Note, Extending Legal Malpractice Liability to Nonclients-The Washington Supreme Court Considers the Privity Requirement-Bowman v. John Doe Two, 61 Wash L Rev 761, 766-69 (1986) (distilling these policy concerns out of cases from several jurisdictions).

${ }^{8}$ Mallen and Smith, 1 Legal Malpractice $\$ 7.10$ at 379 (cited in note 1). See also Donald B. Hilliker, Attorney Liability to Third Parties: A Look to the Future, 36 DePaul L Rev 41, 60-61 (1986) ("Only one case in the last several years has broken the trend to expand third party liability for attorneys.").

- 49 Cal 2d 647, 320 P2d 16 (1958).

${ }^{10} 56$ Cal 2d 583, 15 Cal Rptr 821, 364 P2d 685 (1961).

11 See note 25 and accompanying text.

12 See for example, St. Paul Title Co. v Meier, 181 Cal App 3d 948, 226 Cal Rptr 538, 539 (1986); In re Rexplore, Inc., 685 F Supp 1132, 1146 (N D Cal 1988). 
support elsewhere. Most other states that have lowered the privity bar to legal malpractice claims demand that non-clients be thirdparty beneficiaries before giving them standing to sue. ${ }^{13}$

\section{A. From Privity Bar to Balancing Test}

Winterbottom $v$ Wright ${ }^{14}$ set forth the common law rule of strict privity, holding that no action for negligence could arise outside of a contractual relation. The United States Supreme Court followed suit in Savings Bank $v$ Ward, ${ }^{15}$ but American courts thereafter riddled the privity rule with exceptions. Justice Cardozo led the way in what has become a famous line of opinions. ${ }^{16}$ Cardozo eventually tried to limit the trend toward expanding liability, however, in a case where he observed that "[ $t]$ he assault upon the citadel of privity is proceeding in these days apace."17

Cardozo's observation aptly describes California law. California launched its first major assault on the privity bar to legal malpractice claims in Biakanja $v$ Irving, ${ }^{18}$ where the court allowed the beneficiary of a will to sue the party who negligently prepared it. Citing policy concerns, ${ }^{19}$ Biakanja abandoned the privity rule and instead based standing on the outcome of a test balancing seven factors. The test considered

the extent to which the transaction was intended to affect the plaintiff, the foreseeability of harm to him, the degree of certainty that the plaintiff suffered injury, the closeness of the connection between the defendant's conduct and the injury

\footnotetext{
${ }^{13}$ See, for example, Flaherty o Weinberg, $303 \mathrm{Md} 116,492 \mathrm{~A} 2 \mathrm{~d}$ 618, 625 (1985); Pelham v Griesheimer, 92 Ill 2d 13, 64 Ill Dec 544, 440 NE2d 96, 99-101 (1982).

1410 Meeson \& Welsby 109, 115, in 62 Rev Rep 534, 538 (Ex 1842).

15100 US 195, 203 (1879).

${ }^{16}$ See, for example, MacPherson v Buick Motor Company, 217 NY 382, 111 NE 1050 (1916) (defendant manufacturer found liable for foreseeable injuries to parties lacking privity); Glanzer v Shepard, 233 NY 236, 135 NE 275 (1922) (public weigher held liable for misrepresentation to buyers not in privity where their reliance was the end and aim of the transaction). See Richard A. Posner, Cardozo: A Study in Reputation 107-15 (Chicago, 1990) (discussing this line of cases).

17 Ultramares Corp. $v$ Touche, $255 \mathrm{NY} 170,174 \mathrm{NE} 441,445$ (1931) (barring suit for negligence against public accountant by a party who was meant to benefit only incidentally or collaterally from accountant's services, and was unknown to the accountant).

${ }^{18} 320$ P2d 16.

19 Although the court did not spell out its rationale, it appears to have relied upon the traditional reasons for relaxing the privity barrier to legal malpractice claims: providing a remedy to the victim, placing losses on the responsible attorney, and deterring culpable behavior. See id at 19. See also Note, 61 Wash L Rev at 766-69 (cited in note 7).
} 
suffered, the moral blame attached to the defendant's conduct, and the policy of preventing future harm. ${ }^{20}$

A few years later, in Lucas $v$ Hamm, ${ }^{21}$ the California Supreme Court appeared to modify this list of factors. The court considered an additional factor, not mentioned in Biakanja: whether there would be an undue burden imposed on the legal system. ${ }^{22}$ Furthermore, the court failed to mention "the moral blame attached to a defendant's conduct." Perhaps because both Lucas and Biakanja left open the possibility of variations on their tests, the California courts have not made much of the differences between the cases. ${ }^{23}$ The courts continue to cite each case with roughly equal frequency. ${ }^{24}$

Although the balancing test of legal malpractice liability developed in Biakanja and Lucas has proven popular throughout the United States and has even received favorable notice in England, ${ }^{25}$ this test has not escaped criticism. A Pennsylvania court, for example, rejected the balancing test on grounds that it "has proved un-

${ }^{20} 320 \mathrm{P} 2 \mathrm{~d}$ at 19.

${ }^{21} 364$ P2d 685.

22 Id at 687-88.

${ }^{23}$ The Lucas court also broke new ground in allowing the plaintiff to recover under contract law as a third-party beneficiary. Id at 689 . Later, however, the California Supreme Court dismissed this approach as "conceptually superfluous since the crux of the action must lie in tort in any case; there can be no recovery without negligence." Heyer v Flaig, 70 Cal 2d 223, 74 Cal Rptr 225, 449 P2d 161, 164 (1969). Third-party beneficiary theory has fared better in other states. See Section I.C.

Lucas agreed with Biakanja, however, in implicitly recognizing the policy issues at stake: "plaintiffs would have received the intended benefits but for the asserted negligence of defendant; and if persons such as plaintiffs are not permitted to recover ... the policy of preventing future harm would be impaired." Lucas, 364 P2d at 688.

24 See, for example, Donald v Garry, 19 Cal App 3d 769, 97 Cal Rptr 191, 192 (quoting Biakanja and citing Lucas); Schick v Lerner, 193 Cal App 3d 1321, 238 Cal Rptr 902, 906 (1987) (quoting Lucas and citing Biakanja). Shepardizing the cases via LEXIS on 10/10/92 showed Biakanja having received 152 citations by California courts, while Lucas had received 168. A LEXIS search on the same date retrieved 44 cases citing both Biakanja and Lucas.

28 The balancing test has been favorably received in at least some courts in Arizona, Connecticut, the District of Columbia, Florida, Georgia, Hawaii, Illinois (but see Pelham, 440 NE2d 96), Indiana, Maryland, Minnesota, Mississippi, North Carolina, New Jersey, New Mexico, New York (but see text accompanying notes 35-37), Oregon, Pennsylvania (but see text accompanying note 26), Wisconsin, and England. Mallen and Smith, I Legal Malpractice $\$ 7.11$ at 383-84 n 5 (cited in note 1). See also id at 383 ("The balancing test has been cited with approval and accepted with near unanimity by those jurisdictions which have examined the issue."). See also Note, 61 Wash L Rev at 763 (cited in note 7). 
workable, and has led to ad hoc determinations and inconsistent results." 28

For a time, California minimized such concerns by refusing to hold attorneys liable to third parties who had not been identified to the attorney and who were harmed in arm's length dealings with the attorney's clients. ${ }^{27}$ But California courts upset this neat arrangement by developing a potentially conflicting test of legal malpractice liability: foreseeability of harm to third parties. As a result, the exact boundaries of legal malpractice liability in California currently remain somewhat unclear. ${ }^{28}$

\section{B. Protecting Foreseeably Injured Parties}

In St. Paul Title Co. v Meier, ${ }^{29}$ a California appellate court pared down the balancing test of attorney liability to focus attention on situations in which "the foreseeability of harm to the third party as a consequence of professional negligence is not outweighed by other policy considerations." Pursuing this new route to malpractice liability, a California federal district court found that an attorney could be held liable for advice given to a client when it was foreseeable that the client would use it to solicit potential investors-even though the plaintiff investors were not yet identified to the attorney. ${ }^{30}$ In contrast to the balancing test, the theory that liability for legal malpractice should correspond strictly to foreseeable injuries has found very few followers outside of California. ${ }^{31}$

${ }^{28}$ Guy $v$ Liederbach, $501 \mathrm{~Pa}$ 47, 459 A2d 744, 749 (1983). See also Colaprico v Sun Microsystems, Inc., 758 F Supp 1335, 1339 (N D Cal 1991) ("the test is too pliable, and thus unreliable, for close cases"); Samet, 20 The Brief at 11 (cited in note 6).

${ }^{27}$ Goodman v Kennedy, 18 Cal 3d 335, 134 Cal Rptr 375, 556 P2d 737, 743 (1976) (third-party purchasers of stock barred from suing attorney who had advised corporate officers). But see Roberts v Ball, Hunt, Hart, Brown \& Baerwitz, 57 Cal App 3d 104, $128 \mathrm{Cal}$ Rptr 901, 905 (1976) (attorney's liability reaches identified third parties intended to benefit from his services).

${ }^{28}$ Samet, 20 The Brief at 11 (cited in note 6).

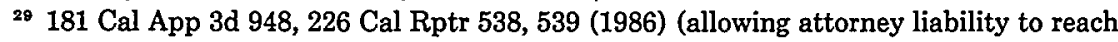
third parties harmed in dealing with clients at arm's length).

${ }^{30}$ In re Rexplore, 685 F Supp 1132, 1144-46 (N D Cal 1988), following St. Paul Title Co., 226 Cal Rptr 538.

${ }^{31}$ Mallen and Smith, I Legal Malpractice $\$ 7.12$ at 390 (cited in note 1); Note, 61 Wash $\mathrm{L}$ Rev at $763 \mathrm{n} 22$ (cited in note 7). But see Samet, 20 The Brief at 12 (cited in note 6), in support of the foreseeability test's prevalence. Samet cites only cases from California and Massachusetts in support of this claim, however, and the other jurisdictions discussed in the same article reveal a decided preference for the intended-beneficiary test. Samet concludes that most jurisdictions do not rely on the foreseeability test. Id at 12-13, 40. 


\section{Intended Third-Party Beneficiary Theory}

Despite the influence of California's legal experimentation, most jurisdictions that have relaxed the privity bar use a thirdparty beneficiary theory to limit the scope of legal malpractice liability to non-clients. In these jurisdictions, both the attorney and the client must intend for their relationship to benefit a third party for liability to that non-client to arise. ${ }^{32}$ Moreover, the intent to benefit the non-client must be the "primary or direct purpose of the transaction or relationship." 33

Why have courts applied the third-party beneficiary approach to limit legal malpractice liability? Further relaxation of the privity bar

would have the undesirable effect of creating a duty to third parties which would take precedence over an attorney's fiduciary duty to his client. Public policy mandates that when an attorney acts in his professional capacity, he must be free to advise his client without fear of personal liability to third persons and nonclients if the advice later proves to be incorrect. ${ }^{34}$

\section{Privity's Last Strongholds}

Ironically, the New York courts that launched the assault on the privity rule during Cardozo's tenure are today some of its last defenders..$^{35} \mathrm{~A}$ state's faith in the privity rule can be gauged by looking at how it treats claims by would-be beneficiaries of wills, sympathetic plaintiffs who stand ready and willing to defend testators' rights. ${ }^{36}$ In Viscardi $v$ Lerner, the New York Appellate Division "decline[d] to depart from the firmly established privity re-

${ }^{32}$ See, for example, Flaherty, 492 A2d at 625-27. Not all courts require an explicit statement of an intent to benefit a third party, however. See, for example, Hale $v$ Groce, 304 Or 281, 744 P2d 1289, 1292 (1987) (non-client plaintiff not named in will due to admitted failure of testator's attorney given standing to sue as intended third-party beneficiary); Stowe v Smith 184 Conn 194, 441 A2d 81, 83 (1981) (non-client plaintiff has standing to sue attorney who contravened testator's instructions to leave plaintiff the principal of a testamentary trust).

ss Pelham, 440 NE2d at $99-101$.

s4 Orr v Shepard, 171 Ill App 3d 104, 121 Ill Dec 57, 524 NE2d 1105, 1108 (1988) (citations omitted).

${ }^{35}$ See, for example, Viscardi $v$ Lerner, 125 AD2d 662, 510 NYS2d 183, 185 (1986) (affirming New York's traditional support of the strict privity rule in attorney malpractice cases).

se Mallen and Smith, 1 Legal Malpractice $\$ 7.10$ at 379 (cited in note 1); Note, 61 Wash $\mathrm{L} \mathrm{Rev}$ at 764 (cited in note 7) ("Beneficiaries failing to take under invalid wills often present compelling claims for relief."). 
quirement in order to create a specific exemption for an attorney's negligence in will drafting." 37 No more than a handful of other states also stand by the strict privity rule when it would bar recovery by third-party beneficiaries of wills. Only courts in Missouri, Nebraska, Ohio, and Texas still treat the absence of privity as a bar to recovery in such cases. ${ }^{38}$ These exceptions notwithstanding, most jurisdictions have either lowered the privity bar to legal malpractice claims or removed it altogether..$^{39}$

\section{The Case for Restrictions on Assignment of Legal Malpractice Claims}

Courts have for the most part frowned on the assignment of legal malpractice claims, voicing concern that it threatens important public policy interests. The policy interests cited tend to vary, however, depending on whether a court addresses a voluntary assignment, such as one which would arise out of a free exchange for mutual benefit, or an involuntary assignment, such as one arising out of a court order for payment of a debt. Courts have generally worried that allowing voluntary assignments of legal malpractice claims would place undue burdens on attorneys and courts. ${ }^{40}$ Only one court has offered any policy arguments to the contrary. ${ }^{41} \mathrm{With}$ regard to the involuntary assignment of legal malpractice claims, however, attention has focused on protecting the interests of the parties to the underlying cause. ${ }^{42}$

\section{A. Voluntarily Assigned Claims}

Although privity doctrine in the area of legal malpractice liability is fairly well developed, courts have seldom grappled with

37510 NYS2d at 185. See also Rossi v Boehner, 116 AD2d 636, 498 NYS2d 318 (1986).

${ }^{38}$ Williams v Bryan, Cave, McPheeters, McRoberts, 774 SW2d 847, 849 (Mo App 1989); Landrigan v Nelson, $227 \mathrm{Neb} 835,420$ NW2d 313, 314 (1988); Lilyhorn v Dier, 214 Neb 728, 335 NW2d 554, 555 (1983); Simon v Zipperstein, 32 Ohio St 3d 74, 512 NE2d 636, 638 (1987); Dickey $v$ Jansen, 731 SW2d 581, 582 (Tex App 1987). See also Helen Bishop Jenkins, Privity-A Texas-Sized Barrier to Third Parties for Negligent Will Drafting-An Assessment and Proposal, 42 Baylor L Rev 687, 697-98 (1990).

${ }^{38}$ Mallen and Smith, 1 Legal Malpractice $\$ 7.10$ at 379 (cited in note 1). See also Hilliker, 36 DePaul L Rev at 60 (cited in note 8).

to See, for example, Goodley, $133 \mathrm{Cal}$ Rptr at 86; Jackson v Rogers and Wells, $210 \mathrm{Cal}$ App 3d 336, 258 Cal Rptr 454, 460 (1989).

41 Hedlund Manufacturing Co., Inc. v Weiser, Stopler \& Spivak, 517 Pa 522, 539 A2d 357,359 (1988).

${ }^{42}$ See, for example, Kracht v Perrin, Gartland \& Doyle, 219 Cal App 3d 1019, $268 \mathrm{Cal}$ Rptr 637, 640 (1990). 
the voluntary assignability of legal malpractice claims. They have allowed it even less frequently.

Goodley $v$ Wank \& Wank, Inc., ${ }^{43}$ decided by a California appellate court, is the main source for the proposition that legal malpractice claims should not be assignable. The Goodley court held that the unique nature of legal services and the attorney-client relationship invoked public policy concerns precluding voluntary assignment. ${ }^{44}$ It described these public policy concerns at length in an oft-quoted passage:

The almost certain end result of merchandizing such causes of action is the lucrative business of factoring malpractice claims which would encourage unjustified lawsuits against members of the legal profession, generate an increase in legal malpractice litigation, promote champerty and force attorneys to defend themselves against strangers. The endless complications and litigious intricacies arising out of such commercial activities would place an undue burden on not only the legal profession but the already overburdened judicial system, restrict the availability of competent legal services, embarrass the attorney-client relationship and imperil the sanctity of the highly confidential and fiduciary relationship existing between attorney and client. ${ }^{45}$

In Jackson $v$ Rogers \& Wells, ${ }^{46}$ another -California appellate court followed Goodley and expanded on its rationale. First, the Jackson court expressed concern that assignment would impair attorney-client relations by enabling strangers or adversaries to take

${ }^{43} 62$ Cal App 3d 389, 133 Cal Rptr 83 (1976). The court ignored a previous decision that had let pass without comment a legal malpractice action brought by an assignee: Lysick v Walcom, $258 \mathrm{Cal}$ App 2d 136, 65 Cal Rptr 406 (1968).

14 133 Cal Rptr at 85-88.

45 Id at 87. This passage is quoted, for example, in Continental Casualty Co. v Pullman, Comley, Bradley \& Reeves, 709 F Supp 44, 50-51 n 7 (1989); Brocato v Prairie State Farmers Ins. Ass'n, 166 Ill App 3d 986, 520 NE2d 1200, 1202 (1988); Picadilly, Inc. $v$ Raikos, 582 NE2d 338, 342 (Ind 1991). The Goodley quote contains some seldom-heard terms that merit definition. "Champerty" arises in a "bargain between a stranger and a party to a lawsuit by which the stranger pursues the party's claim in consideration of receiving part of any judgment proceeds; it is one type of 'maintenance' . . ." Black's Law Dictionary 231 (West, 6th ed 1990). "Maintenance" means "officious intermeddling in a lawsuit by a non-party by maintaining, supporting or assisting either party, with money or otherwise, to prosecute or defend the litigation." Id at 954. "Factoring" is "[t]he purchase of accounts receivable [here legal claims] by a factor who thereby assumes the risk of loss for some agreed discount." Id at 592. Finally, a "factor" is a "commercial agent to whom the possession of personalty is entrusted by or for the owner, to be sold, for a compensation, in pursuance of the agent's usual trade or business. . . ." Id.

${ }^{48} 210$ Cal App 3d 336, 258 Cal Rptr 454 (1989). 
up clients' legal malpractice claims. ${ }^{47}$ The court theorized that this threat might discourage an attorney from "pursuing vigorous advocacy on behalf of his or her client" for fear of annoying the adversary, who might seek vengeance by suing the attorney for malpractice under an assignment of rights. ${ }^{48}$

Second, the Jackson court expressed concern that allowing legal malpractice claims to be bought and sold would inevitably raise attorneys' insurance premiums. ${ }^{49}$ Lastly, the Jackson court contended that circumstances surrounding this assignment rendered the claim "fraught with illogic." posed the assignor in a prior case and won an excessively large recovery due to the negligence of the assignor's attorney. By taking up his former adversary's legal malpractice claim the assignee argued, in effect, that his prior recovery should have been diminished. ${ }^{51}$

Most jurisdictions that have addressed the voluntary assignment of legal malpractice claims have found the reasoning of Goodley and Jackson persuasive. ${ }^{52}$ In only a few cases have courts allowed the voluntary assignment of legal malpractice claims. ${ }^{53}$ The opinions in these cases typically fail to identify reasons for their conclusions, but the Pennsylvania case of Hedlund Manufacturing Co., Inc. $v$ Weiser, Stapler \& Spivak provides the notable exception. ${ }^{54}$

47258 Cal Rptr at 461-62.

${ }^{48}$ Id at 461 . The court apparently assumed that employer-insurers would purchase their employee-clients' causes of action in settlement.

49 Id. This objection is addressed below along with the Goodley court's complaint about overburdening the legal profession and restricting the availability of competent legal aid. See text accompanying notes $109-28$.

so Id.

51 Id at 461-62. See also Kracht, $268 \mathrm{Cal}$ Rptr at 641 (legal malpractice claim against defendant's attorney, when assigned to victorious plaintiff, requires her to aver that "To the extent I was not entitled to recover [but did, because of defense counsel's negligence], I am now entitled to recover").

${ }^{52}$ See, for example, Schroeder v Hudgins, 142 Ariz 395, 690 P2d 114, 118-19 (Ct App 1984); Brocato, $520 \mathrm{NE2d}$ at 1202; Coffey $v$ Jefferson County Board of Education, 756 SW2d 155, 157 (Ky App 1988); Chaffee v Smith, 98 Nev 222, 645 P2d 966 (1982).

${ }^{83}$ See, for example, Oppel v Empire Mutual Ins. Co., 517 F Supp 1305, 1307 (S D NY 1981) (distinguishing between "personal injury" and "only pecuniary" legal malpractice claims; allowing the latter); McGill v Lazzaro, 62 Ill App 3d 151, 19 Ill Dec 501, 379 NE2d 16, 18 (1978) (citing the "general rule" that actions for fraud, negligence, or bad faith can be assigned); American Hemisphere Marine Agencies, Inc. v Kreis, 40 Misc 2d 1090, 244 NYS2d 602, 603 (Sup Ct 1963).

${ }_{54} 517$ Pa 522, 539 A2d 357 (1988). For an analysis of Hedlund see Recent Decisions: Assignments-Attorney and Client, 27 Duquesne L Rev 851 (1989). 
In Hedlund, the plaintiff was assigned both the rights to a patent and to a claim against the attorney who had filed the patent late. Despite objections from the defendant-attorney, the Hedlund court upheld the validity of the assignment of the legal malpractice claim. It side-stepped Pennsylvania's strict privity rule by finding that the assignee stood in the shoes of his assignor. ${ }^{.55}$ While recognizing the rule against assigning personal injury claims, the court explained that "a claim for damages based upon legal malpractice does not involve personal injury in that it arises out of negligence and breach of contract, and the injury alleged concerns purely pecuniary interests." $" 56$ The court denied that allowing assignability would harm the attorney-client relationship, explaining that in a legal malpractice claim there is no attorney-client relationship to protect. ${ }^{57}$ The Hedlund court concluded that public policy favored allowing voluntary assignments.

\section{B. Involuntarily Assigned Claims}

The involuntary assignment of legal malpractice claims raises issues not addressed in Goodley and Jackson, both of which concerned assignments undertaken with the full consent of both assignor and assignee. Involuntary assignments take place by operation of law, and typically put the legal malpractice claim in the hands of a deceased client's estate, a trustee or creditor in bankruptcy, or a subrogating insurer. ${ }^{58}$ Courts addressing these conventional situations have generally allowed the involuntary assignment of the legal malpractice claim at issue. For example, courts usually permit a legal malpractice claim to vest in the estate of a deceased client. ${ }^{59}$ Most jurisdictions likewise accept involuntary assignments in cases where a bankrupt's legal malpractice claim has become part of his or her bankruptcy estate. ${ }^{60}$ Courts have also allowed

\footnotetext{
s6 539 A2d at 358.

68 Id at 359 .

67 Id.

${ }^{68}$ Although "involuntary assignment" merits respect as a term of art, "nonvoluntary assignment" would arguably serve better. See text accompanying notes 145-48.

${ }^{s 9}$ See, for example, Saltmarsh v Burnard, 151 Mich App 476, 391 NW2d 382 (1986); McFail v Braden, 19 Ill 2d 108, 166 NE2d 46 (1960).

${ }^{B 0}$ See, for example, Collins v Federal Land Bank of Omaha, 421 NW2d 136, 138-39 (Iowa 1988); DeLarco v DeWitt, 136 AD2d 406, 527 NYS2d 615, 616 (1988). But see Christison v Jones, 83 Ill App 3d 334, 39 Ill Dec 560, 405 NE2d 8, 11-12 (1980) (following Goodley; treating assignment of malpractice claim to a bankrupt's estate as no different than assignment of the claim to anyone else).
} 
insurers to subrogate legal malpractice claims, though with less consistency. ${ }^{61}$

The California appellate court in Kracht v Perrin, Gartland \& Doyle ${ }^{62}$ addressed a less conventional sort of involuntary assignment. The assignment took place under compulsion of a court order designed to satisfy debts the assignor owed the assignee. The Kracht court argued that the involuntary nature of the assignment presented two unique threats to public policy. First, a malpractice claim might be filed despite opposition from a client who had no complaints about legal services he or she had received. ${ }^{63}$ Second, the involuntary assignment of a legal malpractice claim could unfairly prejudice "either the attorney (by precluding any defense based on privileged communications) or the client (by permitting the assignee to waive the privilege without the client's consent)." Valid or not, these arguments concern only assignments of the sort before the Kracht court. As noted below, more conventional types of assignments merit a different and more lenient treatment. ${ }^{68}$

\section{The Nature of the Conflict}

The conflict between lowering the privity bar to legal malpractice claims and restricting the assignability of legal malpractice claims arises because the arguments that courts cite in favor of the former disfavor the latter. Conversely, the courts' arguments for disallowing assignability work against relaxing the privity bar.

The tension between these two bodies of case law appears clearly whether viewed from the perspective of either privity or assignability. From the perspective of privity, courts aim to fulfill a number of policies by relaxing the privity bar to legal malpractice claims: providing remedies to victims of legal malpractice, making responsible attorneys bear the costs, and deterring culpable behavior. ${ }^{66}$ Permitting voluntary assignments would satisfy each of these policies to a degree comparable to or greater than would relaxing

${ }^{61}$ See, for example, Great Atlantic Insurance Co. $v$ Weinstein, 125 AD2d 214, 509 NYS2d 325 (1986) (allowing the subrogation of a legal malpractice claim to pass without comment). But see American Employer's Insurance Co. v Medical Protective Co., 165 Mich App 657, 419 NW2d 447, 448-49 (1988) (assignment refused on grounds that attorney would fail to represent clients zealously if made liable to both them and their insurers).

62 219 Cal App 3d 1019, 268 Cal Rptr 637 (1990).

es 268 Cal Rptr at 640.

${ }^{64}$ Id at $641 \mathrm{n} 6$. The court cited no evidence, however, that the client had actually objected to the malpractice suit or to the waiver of attorney-client privilege.

${ }^{\text {os }}$ See Section IV.B.7.

${ }^{68}$ See, for example, Biakanja, 320 P2d at 19; Lucas, 364 P2d at 688. 
the privity rule, while producing no adverse consequences suffcient to justify prohibiting the practice. ${ }^{87}$

From the perspective of assignability, few of the arguments made against the assignment of legal malpractice claims stand up to close scrutiny. When not entirely amiss, these arguments speak with equal or greater force against lowering the privity bar. For the most part, then, relaxing the privity requirement and allowing assignability stand or fall by the same arguments. To reconcile these bodies of case law, this Comment argues that courts should lower the privity bar only enough to allow claims by intended beneficiaries and should abolish current barriers to voluntary assignments. Relaxing the privity rule does, however, sometimes influence legal malpractice claims in different ways than allowing assignability would. More often than not, these differences favor the latter policy. But they also demonstrate that lowering the privity bar serves special ends.

The most important difference between lowering the privity bar and allowing assignability relates to the efficiency with which these policies resolve legal malpractice claims. As discussed in Section IV, allowing voluntary assignability would promote the optimal enforcement of legal rights by putting them in the hands of the parties who value them most. ${ }^{68}$

Another difference between lowering the privity bar and allowing assignability is that the former may greatly expand the class of plaintiffs who have standing to bring legal malpractice claims. For example, in In re Rexplore, Inc., the court gave standing to third-party investors, whom the defendant-attorney did not know, on the grounds that they suffered foreseeable harms from arms-length dealings with a client acting on the attorney's advice. ${ }^{69}$ Lowering the privity bar to this extent may make it difficult for attorneys to ascertain to whom, and thus to what extent, they will be held liable for their errors. Many defendants are surprised by what courts judge to have been foreseeable. Allowing assignment, in contrast, leaves the criteria for legal malpractice unaffected.

Although relaxing the privity bar might promise standing to sympathetic plaintiffs more frequently than expanding assignability would, the policy should not be taken too far. Fairness de-

\footnotetext{
67 See text accompanying notes 84-96.

68 See text accompanying notes $87-88$. To a lesser degree the same is also true of one class of involuntary claims, described below as "nonvoluntary." See text accompanying notes $145-48$.

68 685 F Supp 1132, 1146 (N D Cal 1988).
} 
mands that attorneys be held liable for harms inflicted on their clients' intended beneficiaries. But public policy demands that attorneys' liability to non-clients go no further. ${ }^{70}$ Voluntary assignability offers no more standing to third-party beneficiaries than they are willing to purchase, but it promotes fairness by another route: it helps to ensure that victims of legal malpractice know their rights and that they obtain relief quickly and easily. ${ }^{71}$

The temptation to portray relaxing the privity bar as only an equitable policy and allowing assignability as only an efficient one should therefore be resisted. Just as voluntary assignability speaks to more than efficiency, courts do not relax privity requirements just to give standing to every sympathetic party who complains about legal malpractice. ${ }^{72}$ Instead, they aim at broader policies-policies with respect to which assignability often offers distinct advantages. ${ }^{73}$

\section{Resolving the Conflict}

Broadly speaking, courts can resolve the conflict that arises from simultaneously relaxing privity requirements and disallowing assignability either by abandoning one policy or by withdrawing from both to reach a comfortable medium. Simply resurrecting the privity bar would leave many policy concerns unaddressed and run against prevailing jurisprudential trends. Nonetheless, the uncertainty generated by California's balancing test shows the hazards of taking the assault on privity too far. ${ }^{74}$ Courts ought to lower the privity bar only low enough to let intended beneficiaries pass.

${ }^{70}$ See Orr, 524 NE2d at 1108 ("Public policy mandates that when an attorney acts in his professional capacity, he must be free to advise his client without fear of personal liability to third persons and nonclients if the advice later proves to be incorrect.").

71 See text accompanying notes 90-94.

72 See, for example, Goodman v Kennedy, 18 Cal 3d 335, 134 Cal Rptr 375, 556 P2d $737,743-44$ (1976). One might even argue that courts have acted efficiently in relaxing privity requirements for legal malpractice claims on the grounds that legal services are frequently "credence goods" - that is, consumers find it difficult to determine their value even after substantial use. A lawyer is far better placed to evaluate and insure against the risks of using the lawyer's legal services than is a client or third parties. For an analogous discussion with regard to product liability, see William M. Landes and Richard A. Posner, The Economic Structure of Tort Law 284-88 (Harvard, 1987).

${ }^{73}$ Such policies include providing remedies to victims of legal malpractice, forcing negligent attorneys to bear the costs of their behavior, and deterring legal malpractice. See text accompanying note 7 .

7 See text accompanying notes $25-26$. 
If courts have given the merits of privity too little respect, they have virtually ignored the merits of assignability. Allowing the voluntary assignment of legal malpractice claims would serve the same policies that courts have voiced to justify relaxing the privity bar-with even greater efficiency. ${ }^{75}$ The charges that courts have launched against voluntary assignability fail to stand up to close scrutiny. But like the assault on privity, the loosening of restrictions on assignability ought not be allowed to go too far. Courts should guard against the sorts of abuse to which all assignable claims are susceptible and prohibit involuntary assignments of legal malpractice claims that would violate the confidentiality of attorney-client relations. With these checks in place, however, allowing greater assignability of legal malpractice claims promises to bring about gains in both efficiency and equity.

\section{A. Resurrecting the Privity Bar}

Resurrecting the privity bar would give courts one means of avoiding the apparent conflict between policy arguments for relaxing privity and policy arguments for restricting assignment. Absent other measures, however, this would abandon the policy goals that justified lowering the privity bar in the first place. Courts are thus understandably reluctant to return to the strict privity bar. ${ }^{76}$

As even California courts have recognized, however, excessively relaxing privity sacrifices other important policy goals. Overextending legal malpractice liability to parties not in privity undermines certainty in judicial decisionmaking by replacing the square corners obtainable in a contractual relationship with complex balancing tests and disputable determinations regarding foreseeability. The resulting uncertainty promotes wasteful litigation between parties unable to settle on objective valuations of malpractice claims, ${ }^{77}$ and discourages attorneys from zealously representing their clients by raising the spectre of liability to third parties. ${ }^{78}$ Courts can account for these concerns by allowing the voluntary assignment of legal malpractice claims, rather than assaulting privity. Assignability makes attorneys bear the costs of their actions and deters further malpractice even better than re-

\footnotetext{
${ }^{75}$ Again, the same is true of nonvoluntary assignments, but to a lesser degree. See text accompanying notes $145-48$.

76 See text accompanying notes 6-13.

77. See text accompanying notes 84-87.

78 See Orr, 524 NE2d at 1108; Hilliker, 36 DePaul L Rev at 63 (cited in note 8); Note, 61 Wash L Rev at 777 (cited in note 7).
} 
laxing the privity rule. ${ }^{79}$ Allowing voluntary assignability also helps victims of legal malpractice to secure remedies. ${ }^{80}$ Yet assignability carries few of the negatives that follow overly ambitious assaults on privity.

Only with regard to granting legal standing does relaxing privity requirements offer special tools for dealing with legal malpractice. But to avoid the hazards of overextending attorney liability, courts should lower the privity bar only when they. can preserve clear boundaries to attorney liability, when clients will not bring suit, and when equity demands. Among current-approaches to privity, only the intended beneficiary test meets these standards. ${ }^{81}$ Courts should adopt this test, but once they have applied it to establish who has legal-standing to sue for legal malpractice, they should forget privity and employ the most effective tool for correcting, punishing, and deterring legal malpractice: allowing voluntary assignments.

\section{B. Allowing the Assignment of Legal Malpractice Claims}

Relaxing restrictions on voluntary assignability offers courts the best means of escaping the inconsistency of lowering the privity bar to legal malpractice claims while simultaneously restricting their assignability. Furthermore, by bringing market reforms to the legal system, allowing the voluntary assignment of legal malpractice claims would improve the efficiency and equity of mechanisms for correcting and preventing legal malpractice.

Allowing parties to assign voluntarily their legal malpractice claims promises to ease overall burdens on the legal system. Under the present system, plaintiffs lacking information about the value of their claims will often take them to court in ignorance of whether their litigation costs will exceed their returns. ${ }^{\mathbf{8 2}}$ Voluntary assignability can reduce such litigation by educating potential plaintiffs about the value of their claims. ${ }^{83}$ It would permit a com-

29 See text accompanying notes 87-88.

so See text accompanying notes 90-94.

81 See section I.C.

82 A great deal of scholarship has developed around the question of why parties litigate. See, for example, Samuel R. Gross and Kent P. Syverud, Getting to No: A Study of Settlement Negotiations and the Selection of Cases for Trial, 90 Mich L Rev 319 (1991); George L. Priest, Issues in Civil Procedure: Advancing the Dialogue, 69 BU L Rev 527 (1989); George L. Priest and Benjamin Klein, The Selection of Disputes for Litigation, $13 \mathrm{~J}$ Legal Stud 1 (1984).

${ }^{83}$ To a lesser degree the same is true of that class of involuntary assignments described below as being nonvoluntary. See text accompanying notes 145-48. 
petitive market in legal malpractice claims to arise, and thus generate information about the value of claims by ascribing them prices. ${ }^{84}$ Assignability would foster a more objective valuation of claims drawing on the expertise of specialists in such estimations. This would encourage settlement because parties will tend to arrive at more uniform valuations. ${ }^{85}$

Allowing voluntary assignability may also provide an optimally efficient mechanism for enforcing laws against legal malpractice. ${ }^{88}$ A market in legal malpractice claims would tend to place them in the hands of the parties who value them most. ${ }^{87}$ In cases in which these parties are not defendant-lawyers settling out of court, they will be the parties most willing and able to litigate the claims. By encouraging private parties to enforce legal malpractice laws, allowing voluntary assignability will thus force negligent attorneys to bear the costs of their actions and deter other attorneys from engaging in malpractice.

Market reform of the legal system would increase its equity as well as its efficiency. Tort victims seeking compensation from tortfeasors usually find themselves in a distinctly poor bargaining position. ${ }^{83}$ They may need immediate funds due to the losses they have suffered. They may also lack the expertise to evaluate realistically their legal options. ${ }^{89}$ This holds especially true of the victims of legal malpractice, who are likely to square off against opponents more wealthy and skilled than themselves.

A market in legal malpractice claims already exists, in a sense, but it is a monopsony where only defendant-attorneys have the right to purchase the claims brought against them (by settling out of court). Opening this market to third parties would eliminate the unfair advantage currently held by attorneys guilty of malpractice, who can threaten their victims with the choice between a low set-

at See Goetz, Law and Economics at 42 (cited in note 3) (discussing the information generating benefits of a market created by contingency fees and subrogation); Weinberg, 64 $\mathrm{Ky} \mathrm{L} \mathrm{J} \mathrm{at} 75$ (cited in note 3).

${ }^{85}$ Goetz, Law and Economics at 43. See also Cooter, $75 \mathrm{Va} \mathrm{L} \mathrm{Rev} \mathrm{at} \mathrm{397-98} \mathrm{(cited} \mathrm{in}$ note 3 ). Both sources describe the settlement of tort claims generally, though by extension their observations apply to legal malpractice claims.

so An argument by analogy from Cooter, $75 \mathrm{Va} \mathrm{L} \mathrm{Rev} \mathrm{at} \mathrm{396-400.} \mathrm{See} \mathrm{also} \mathrm{Shukaitis,} 16$ J Legal Stud at 341 (cited in note 3); Jonathan R. Macey and Geoffrey P. Miller, The Plaintiffs' Attorney's Role in Class Action and Derivative Litigation: Economic Analysis and Recommendations for Reform, $58 \mathrm{U}$ Chi L Rev 1, 105-16 (1991).

s7 See Macey and Miller, $58 \mathrm{U}$ Chi $\mathrm{L}$ Rev at 110 (referring to a market in class action and derivative claims); Goetz, Law and Economics at 43 (cited in note 3) (referring to a market in tort claims generally).

ss Shukaitis, $16 \mathrm{~J}$ Legal Stud at 334-35 (cited in note 3).

so Id at 337 . 
tlement and an expensive court battle. ${ }^{.0}$ Under a system allowing assignment, such attorneys would not continue to enjoy the unfair advantages of wealth and expertise, for to settle the claims against them they would have to bid more than competing purchasers. ${ }^{91}$ Such competition would help to inform victims of legal malpractice of their rights and offer them immediate compensation. ${ }^{92}$

Courts already allow the assignment of most property and contract-related claims and of many types of tort claims. ${ }^{93}$ They thus have readily adaptable tools for dealing with the abuses that might accompany the voluntary assignment of legal malpractice claims. As for involuntary assignments, courts are already learning to screen out those that threaten the confidentiality of attorneyclient relations. ${ }^{94}$ This Section criticizes the arguments that courts have brought to bear against the assignability of legal malpractice claims and argues that assignability offers far more benefits than liabilities.

1. Unique nature of the legal profession.

The Goodley court disallowed the assignment of legal malpractice claims due to the "uniquely personal nature of legal services." 95 The Supreme Court, however, has argued against sheltering lawyers from market forces. In Bates $v$ State Bar of Arizona, the Court explained that "the belief that lawyers are somehow 'above' trade has become an anachronism." In so arguing, the Court "acknowledged the obvious once and for all-that lawyering is a business. . . .".97

\footnotetext{
${ }^{90}$ See id at 336; Cooter, $75 \mathrm{Va} \mathrm{L} \mathrm{Rev} \mathrm{at} 404$ (cited in note 3).

a1 As discussed above, this bidding process may result in victims being offered the "true" value of their claims. Would it result in "fair" offers? That depends on whether courts treat victims of legal malpractice fairly, since the offers they get for their claims track what they would get in court. But assignability deserves none of the credit or blame on this count.

${ }^{92}$ See Shukaitis, $16 \mathrm{~J}$ Legal Stud at 334-38 (cited in note 3) (referring to a market in personal tort claims).

${ }^{\text {93 }}$ See, for example, Osuna v Albertson, 134 Cal App 3d 71, 184 Cal Rptr 338, 345 (1982); Weinberg, $64 \mathrm{Ky} \mathrm{L} \mathrm{J} \mathrm{at} \mathrm{74-78} \mathrm{(cited} \mathrm{in} \mathrm{note} \mathrm{3);} \mathrm{Goetz,} \mathrm{Law} \mathrm{and} \mathrm{Economics} \mathrm{at} 39$ (cited in note 3 ).

94 See text accompanying notes 64-65.

95133 Cal Rptr at 86.

${ }^{96} 433$ US 350, 371-72 (1977) (striking down prohibitions on attorney advertising). But see Ohralik v Ohio State Bar Ass'n, 436 US 447, 460 (1978) (although self-employed business agents, lawyers are also trusted agents of their clients and assistants to the court).

${ }_{97}$ Duncan A. McDonald, Speculations by a Customer About the Future of Large Law Firms, 64 Ind L J 593, 594 n 4 (1989). See also Norman Bowie, The Law: From a Profession to a Business, 41 Vand L Rev 741 (1988).
} 
The arguments of the Goodley court merit little regard insofar as they merely ask that lawyers get special protection from the rigors of a market in legal malpractice claims. Why should lawyers get privileged treatment? As will be discussed below, sheltering lawyers from assigned claims serves neither clients nor the legal system..$^{98}$

2. Legal malpractice as a personal tort.

In Goodley, the court explained that "the personal nature of the attorney's duty to the client" triggers public policy concerns precluding the assignment of legal malpractice claims. ${ }^{99}$ Describing legal malpractice claims in this manner allowed the Goodley court to subject them to the common law rule that forbids the assignment of personal injury claims. ${ }^{100}$

Legal malpractice, however, need not be considered solely a personal tort. Because a client's injury typically consists of pecuniary rather than physical harms and arises out of a contractual relation, at least one court has explicitly classified legal malpractice as a tort against property. ${ }^{101}$ Other courts seem prepared to do the same. ${ }^{102}$ Even the Goodley court left this possibility open. ${ }^{103}$

Because legal malpractice claims mix the qualities of personal torts and torts against property, courts should not automatically classify them only by reference to the former. Most courts allow parties not in privity to recover for injuries due to legal malpractice. Many will even let a complete stranger to the attorney bring suit. ${ }^{104}$ Courts can thus scarcely maintain that legal malpractice is inherently personal.

Even if courts persist in categorizing legal malpractice claims as personal torts, the traditional rule of non-assignability still should not apply. Support has grown for repealing the rule alto-

98 See text accompanying notes 108-35.

9 133 Cal Rptr at 87.

${ }^{100}$ Id at 84-87. This is an exception to the general rule favoring the assignment of nonpersonal injury claims. See text accompanying note 95.

101 Hedlund, 539 A2d at 359 (citations omitted).

102 See, for example, Christison v Jones, 83 Ill App 3d 334, 405 NE2d 8, 11 (1980).

103133 Cal Rptr at 87.

[T] $\mathrm{T}$ he personal nature of the duty owed to the client does not perforce convert the breach thereof to a "tort of a purely personal nature" . . . but neither does the damage alleged to be a direct consequence of defendants' negligent breach of duty convert it to a claim "for property damages" arising out of a "non-personal tort" that is freely assignable.

104 See, for example, In re Rexplore, 685 F Supp at 1143-47. 
gether. ${ }^{105}$ Modern commentators who have examined the issue agree that " $[t]$ he reasons that may have once supported restricting the transferability of tort claims, such as the fear of maintenance and difficulties in valuation, are not persuasive in contemporary society."106 Perhaps such comments herald the final steps in a long term trend toward allowing the free assignability of all causes of action. ${ }^{107}$

\section{Fear of a market in legal malpractice claims.}

In Goodley, the court expressed concern that an open market in legal claims would put an undue burden on both the legal system and the legal profession by encouraging unjustified litigation. ${ }^{108}$ This argument is open to attack on a number of fronts.

First, the Goodley court's argument appears to prove too much. It applies to the assignability of any sort of legal claim, including those currently considered assignable. ${ }^{109}$ The court gives no reason to fear that legal malpractice claims will generate more illegitimate suits than alternative claims that are already freely assignable. In any case, the proper remedy is not to completely forbid the assignment of legal malpractice claims but to create stricter requirements for them or to enforce pre-existing constraints on frivolous litigation more rigorously. ${ }^{110}$

Second, the Goodley court's concern that allowing assignability would release a flood of legal malpractice claims seems ill-considered, given that the assault on privity may already have had a more profound effect on the number of legal malpractice claims brought before the court. ${ }^{111}$ Relaxing the privity rule increases liti-

105 Although no one has addressed the particular benefits of allowing the assignability of legal malpractice claims, the arguments of commentators addressing the assignability of tort claims in general provide guidance. See note 3 .

${ }^{108}$ Weinberg, $64 \mathrm{Ky} \mathrm{L} \mathrm{J}$ at 98 (cited in note 3). See also Shukaitis, $16 \mathrm{~J}$ Legal Stud at 348-49 (cited in note 3).

107 See, for example, Osuna, $184 \mathrm{Cal}$ Rptr at 345 ("the tendency of modern jurisprudence strongly favors the assignability ... of things in action") (emphasis in original), citing Estate of Baker, 170 Cal 578, 150 P 989, 993 (1915).

108133 Cal Rptr at 87.

109 Such as most property and contract claims and most tort claims not arising out of a personal injury. See note 4 and text accompanying note 95 .

110 Courts might, for example, sanction the attorney via FRCP 11 or draw the bar's attention to violations of the Model Rules. See ABA Model Rules of Professional Conduct, Rule 3.1 ("[a] lawyer shall not bring a proceeding, or assert or controvert an issue therein, unless there is a basis for doing so that is not frivolous").

11 The available data supports this hypothesis. The percentage of legal malpractice claims initiated by non-clients to all legal malpractice claims more than doubled in the period from 1979 to 1985, beginning at $7 \%$ and ending at $19 \%$. Standing Committee on Law- 
gation by creating claims where none would otherwise exist and increasing the number of parties to already existing claims. These effects would greatly subside if the privity bar were lowered only enough to let intended beneficiaries pass-a reform suggested as complementary to that of allowing voluntary assignments.

In contrast, permitting the voluntary assignment of legal malpractice claims should have a small or negative impact on the number of cases litigated. Because permitting the voluntary assignment of legal malpractice claims will tend to put them in the hands of the parties who value them most, the concern that expert attorneys will snap them up in the expectation of litigating them for profit may be justified. ${ }^{112}$ Assignability might thus bring a short term marginal increase in the number of legal malpractice claims brought to court. ${ }^{113}$ In the long term, however, "the increased efficiency of the system should improve deterrence and therefore decrease the level of tortious activity." 114 And as noted earlier, the information generated by a market in legal malpractice claims would encourage parties to avoid litigation costs and settle out of court. ${ }^{115}$ Considering the sum of these effects, voluntary assignability should put few or no additional burdens on the legal system. ${ }^{116}$

Ultimately the concern should not be with the mere number of claims, but with the virtues of those that make it to court and with the risk that valid complaints will not get there at all. Justice demands that legitimate claims be heard. As noted earlier, courts that fear meritless suits should set stricter requirements for legal malpractice claims without regard to their origins. ${ }^{117}$ Tightening

yers' Professional Liability, Profile of Legal Malpractice: Report of the National Legal Malpractice Data Center 44-48 (American Bar Association, 1986). This same period saw widespread experimentation with the California balancing test. Mallen and Smith, $1 \mathrm{Legal}$ Malpractice $\$ 7.11$ at 383-84 n 5 (cited in note 1). In California itself, non-client claims averaged $14.7 \%$ of all legal malpractice claims during the period from 1981 to 1985 , versus a national average of $13.3 \%$ during that period. Standing Committee on Lawyers' Professional Liability, Characteristics of Legal Malpractice at 105, 111 (American Bar Association, 1989).

112 If the defendant does not purchase a claim the highest bidder will probably be the most qualified prosecutor. A claim is generally worth more to one more likely to gain from litigating it. See Macey and Miller, $58 \mathrm{U}$ Chi L Rev at 110 (cited in note 87) (discussing a proposed market in class action and derivative claims).

${ }^{113}$ Id. See also Shukaitis, $16 \mathrm{~J}$ Legal Stud at 343-44 (cited in note 3) (discussing the assignability of personal tort claims).

${ }^{114}$ Shukaitis, $16 \mathrm{~J}$ Legal Stud at 343 (referring to a market in personal tort claims).

115 See text accompanying notes $82-85$.

128 See Shukaitis, $16 \mathrm{~J}$ Legal Stud at 343-44 (cited in note 3). See also Goetz, Law and Economics at 43 (cited in note 3) (discussing the impact of allowing the assignment of tort claims in general).

${ }^{122}$ See text accompanying note 111 . 
lax privity rules ought to help. ${ }^{118}$ Allowing voluntary assignments, on the other hand, would provide the best means of ensuring that victims of legal malpractice learn their rights and attract the parties most qualified to protect them. ${ }^{119}$ Parties with most other sorts of enforceable legal claims have won the benefits of assignability. ${ }^{120}$ Victims of legal malpractice deserve similar treatment.

In Jackson, the court expressed concern that allowing the assignability of legal malpractice claims would increase burdens on the legal profession by raising lawyers' insurance costs. ${ }^{121}$ But increased insurance rates do not necessarily make for poor policy. To the contrary, they may help to strike a balance between spreading the costs of negligent behavior widely enough to ensure that victims receive adequate recompense and pinning blame on responsible parties by raising their rates. ${ }^{122} \mathrm{~A}$ market in legal malpractice claims may establish the price signals necessary to strike this balance. ${ }^{123}$

The Goodley court also objected to reforming the market for legal malpractice claims on the grounds that doing so would "debase the legal profession."124 But the legal profession's privileged status has already crumbled. ${ }^{125}$ And the array of benefits that would come from allowing legal malpractice claims to be assigned puts the burden of proof on those who would exempt the legal profession from market forces. It is not clear why the legal profession deserves special protection from a mechanism that would prove both efficient and equitable.

One way to explain, but not justify, restrictions on the assignment of legal malpractice claims is by analyzing the interests of the legal profession. Although a few attorneys would profit from the freedom to purchase these claims, every attorney would face greater risks of being caught for malpractice. This may give the bar as a whole strong reasons to oppose the voluntary assignability of legal malpractice claims. ${ }^{26}$ Proposals to allow the voluntary assign-

118 See text accompanying note 77.

118 See text accompanying notes 89-93.

${ }^{120}$ See note 4 and text accompanying note 93 .

121258 Cal Rptr at 461.

${ }^{122}$ See, for example, International Mortgage Co. $v$ John P. Butler Accountancy Corp., $177 \mathrm{Cal} \mathrm{App} \mathrm{3d} \mathrm{806,} 223 \mathrm{Cal}$ Rptr 218, 227 (1986) (discussing the effects of holding accountants liable for professional malpractice).

${ }^{123}$ Cooter, 75 Va L Rev at 396 (cited in note 3).

$124133 \mathrm{Cal}$ Rptr at 87.

125 See text accompanying notes 96-98.

${ }^{128}$ But note that especially good lawyers might, if they thought the matter through, realize that they could gain from a legal regime that more effectively distinguishes them 
ability of legal malpractice claims might thus face the opposition of a powerful and highly motivated special interest group. ${ }^{27}$

\section{Effects on the attorney's diligence.}

The court in Jackson also worried that the voluntary assignment of legal malpractice claims might have an adverse effect on attorney-client relations. According to the court, this relationship "could be impaired if the attorney perceives a future threat of the client's assignment to a stranger or adversary." lieved that an attorney might not be as diligent as he otherwise would be if he fears that such diligence might alienate an adversary who might then sue him for malpractice under an assignment of rights. ${ }^{129}$

Yet courts have better tools for ensuring vigorous advocacy than issuing blanket prohibitions against assignability. State ethics codes incorporating the ABA's Model Rules or Code ${ }^{130}$ should suffice to convince attorneys that half-hearted advocacy affords an extraordinarily poor means of avoiding legal malpractice. ${ }^{131}$ Voluntary assignability will render these and other sanctions against malpractice doubly effective by exposing attorneys to the scrutiny of both the victim-client and his assignees.

Although allowing legal malpractice claims to be voluntarily assigned will probably increase the efficiency with which those claims are pursued, this does not mean that assignment presents greater risks to attorneys than does lowering the privity bar. Some

from their less skilled counterparts. This goes to show that a rigorous public choice analysis of the bar's stance toward the assignment of legal malpractice claims would have to account for a complex range of factors.

${ }^{127}$ Note that this argument applies more forcefully with regard to legal malpractice than with regard to tort claims in general. See Jonathan R. Macey and Geoffrey P. Miller, Toward an Interest-Group Theory of Delaware Corporate Law, 65 Tex L Rev 469, 506-07 (1987) (the bar is an especially well organized, wealthy, and politically powerful interest group).

128 $258 \mathrm{Cal}$ Rptr at 461.

120 Id.

130 See, for example, ABA Model Rules of Professional Conduct, Rule 1.3 ("A lawyer shall act with reasonable diligence and promptness in representing a client."), Rule 1.8 ("Conflict of Interest: Prohibited Transactions"); ABA Model Code of Professional Responsibility, DR 6-101(A)(3) (a lawyer shall not neglect a legal matter entrusted to him), DR 7101(A)(1) (a lawyer shall not intentionally fail to seek the lawful objectives of his client through reasonably available means).

181 How effective are such provisions? Clients do often succeed in forcing attorneys to pay for lax representation. Of all awards claimants won from 1983 to 1985, 8.67\% arose from complaints of inadequate discovery or investigation. Standing Committee, Characteristics of Legal Malpractice at 80 (cited in note 111). 
evidence suggests that relaxing privity errs on the side of allowing too many illegitimate legal malpractice claims. ${ }^{132}$ But assignability might generate objective information about the viability of claims, in the form of evaluations by specialists. ${ }^{133}$ Such market-like valuations would provide objective information to plaintiffs whose initial subjective valuations of their claims are too high. ${ }^{134}$ Assignability should, therefore, lead to less litigation of unjustified claims and help to lower attorneys' risks of facing unjustified accusations of legal malpractice. Such a reform would probably have a more positive impact on lawyers than on other classes of potential defendants; because lawyers value their reputations highly, they are particularly averse to risking accusations of malpractice. ${ }^{135}$ More importantly, reducing unfounded claims would draw out distinctions between good and bad lawyers, thus encouraging malpractice insurers to offer premiums rewarding the latter and punishing the former.

\section{Illogic of championing an opponent's cause.}

The court in Jackson felt that the position of an assignee pressing his opponent's malpractice claim is "fraught with illogic" because "he in effect claims his own recovery ... should have been diminished." ${ }^{136}$ More generally, the problem is one of fighting the battles of a former opponent. The assignor pressing a former opponent's claim must show that the underlying action should have had

${ }^{132}$ Consider that non-clients bringing legal malpractice claims squeeze disproportionately small sums out of attorneys' insurers. During the period from 1983 to 1985 non-clients received $19.1 \%$ of all insurance claim payments between $\$ 0$ and $\$ 1,000,10.1 \%$ of those between $\$ 1,001$ and $\$ 5,000$, and less than $8.7 \%$ in any higher bracket. Id at 63 . Furthermore, $84.9 \%$ of non-clients receiving insurance claim payments received between $\$ 0$ and $\$ 1,000$, compared to $67.0 \%$ of clients. Id. California, the litmus for judging the effects of relaxing privity, saw $19.2 \%$ of its legal malpractice claims dismissed in the years 1981 to 1985, versus a national average of $17.4 \%$. Id at 132,139 . Thus, even though there is no record of what percentage of non-client claims were dismissed, the data available suggests that parties not in privity tend to bring invalid claims.

${ }^{133}$ See Goetz, Law and Economics at 43 (cited in note 3) (making similar argument with regard to tort claims generally).

134 Id.

${ }^{135}$ If the bar presents such a powerful special interest group, why has it not acted on this theory? It may be too subtle an effect to have drawn the bar's attention. Or, even if it has, the bar may be deterred from action because it can enjoy the full benefits of assignability only if courts raise the privity bar. Attorneys may have a general preference for lax privity rules, which create more litigants.

1s6 $258 \mathrm{Cal}$ Rptr at 461. 
an outcome more favorable to the assignee and less favorable to the assignor. ${ }^{137}$

What peril such "illogic" poses, however, is unclear. When an assignee presses a malpractice claim against a former opponent in a case where the assignee had won, the assignee does not put the former judgment at risk. Collateral estoppel protects the judgment that gave rise to the malpractice claim from being reversed later in a legal malpractice hearing. ${ }^{138}$

Perhaps the Jackson court was concerned that the assignee would face a conflict of interest leading the assignee to contradict or dilute the claims originally made against the former adversary, who is now the assignor. Transcripts from the original trial and the doctrine of estoppel provide the legal tools to prevent such hypocrisy, and an attorney facing legal malpractice claims brought by the assignee would have every incentive to wield these tools in defense. ${ }^{139}$

Perhaps the Jackson court worried that allowing an assignee to subsequently press both sides of a case would lend the law an unseemly air of paradox. But this argument proves too much. If the risk of paradox sufficed to discourage legal malpractice litigation, there would be no such litigation at all.

The litigation of a legal malpractice action often thrusts the parties, the judge and the jury into a virtual fantasy world of hypothetical questions of fact and law with assumed plaintiffs and defendants facing theoretical claims of liability and using evidence which is not quite what it seems. . . . The ultimate irony is that the attorney [accused of malpractice] is forced into an adversary position and may oppose the merits of a cause [] he once advocated..$^{140}$

In defense of the Jackson court, one might contrast an attorney forced to defend against a legal malpractice claim and the assignee of such a claim who chooses to step into the shoes of the erstwhile opponent. If courts regard avoiding paradoxes as a vital concern, this distinction might justify forbidding parties from voluntarily contributing to the problem. But avoiding illogic is at best

${ }^{137}$ Mallen and Smith, I Legal Malpractice § 16.1 at 890-91 (cited in note 1).

${ }_{138}$ Mallen and Smith, 2 Legal Malpractice $\$ 17.13$ at 54 (cited in note 1).

${ }^{130}$ See, for example, Hurd $v$ DiMento \& Sullivan, 440 F2d 1322, 1323 (1st Cir 1971) (client suing attorneys for failure to prosecute action estopped from claiming they had agreed to represent her where she had previously sought the action's continuance based on her statement that they had refused to represent her).

${ }^{140}$ Mallen and Smith, I Legal Malpractice $\$ 10.25$ at 623 (cited in note 1). 
only one of many concerns that courts must balance. Deterring legal malpractice and punishing those guilty of it surely count for much, and assignees of legal malpractice claims may be the best parties to advance these ends.

In the end, this issue matters little, as courts can generally avoid illogic without affecting voluntary assignments. The Jackson court prescribed unnecessarily strong medicine. It need only have barred the party who originally opposed the purported victim of legal malpractice from later bringing that claim to court. Nothing in the Jackson court's discussion of illogic speaks against assigning legal malpractice claims to unrelated third parties. The reasoning of the Jackson court does not even rule out assigning a legal malpractice claim to a former adversary-so long as he receives it under condition that he sell the claim to a third party rather than taking it to court himself.

\section{Inventing dissatisfaction.}

The court in Kracht faced a legal malpractice claim that had been assigned involuntarily. It objected that under these conditions "a suit could be filed, even though the former client (to whom the duty was owed) was entirely satisfied with the services and opposed the filing of a malpractice lawsuit." "141 But public policy is best served by aggressively routing out negligent lawyers regardless of how their clients evaluate their services. Otherwise attorneys may convince inexperienced clients to accept substandard legal services.

One might respond that legal malpractice is determined largely by clients' subjective expectations and therefore cannot be determined objectively by third parties. This does not describe the way courts view legal malpractice, however. The standard of proof for establishing that an attorney's malpractice led to an outcome detrimental to the client is "what the result should have been (an objective standard)."142

14268 Cal Rptr at 640 .

${ }_{142}$ Mallen and Smith, 2 Legal Malpractice \$ 27.7 at 641-42 (cited in note 1) (emphasis in original). For cases measuring the attorney's duty to a client against the care and skill of an ordinary reasonable attorney (as opposed to client satisfaction) see, for example, McDaniel v Gile, 530 Cal App 3d 363, 281 Cal Rptr 242, 248-49 (1991); Enriquez v Smith, 173 Cal App 3d 681, 219 Cal Rptr 267, 269 (1985); Glidden v Terranova, 12 Mass App Ct 597, 427 NE2d 1169, 1170 (1981). 
7. Violating the attorney-client privilege.

The Kracht court also objected to allowing the involuntary assignment of legal malpractice claims on the grounds that this practice risked either prejudicing the attorney (by precluding defenses based on confidential communications) or the client (by letting the assignee decide to release such information). ${ }^{143}$ This is an unusual objection. It does not surface when courts deal with conventional types of involuntary assignments, such as those arising by way of death, bankruptcy, or subrogating insurer. Courts typically allow the involuntary assignment of legal malpractice claims in such cases. ${ }^{144}$

Conventional involuntary assignments do not, however, present the same risks that attended the assignment before the Kracht court. The assignee there involuntarily lost his legal malpractice claim because his creditor obtained a court order directing him to assign the claim. In contrast, deceased clients cannot complain if others take up their claims, ${ }^{145}$ and clients who enter into bankruptcy or sign insurance contracts agree to sacrifice their legal rights in exchange for something they desire more (protection from creditors or from risks). ${ }^{146}$ These last three types of assignments (death, bankruptcy, or subrogating insurer) ought to be called nonvoluntary. Only assignments like the one in Kracht fully merit the label involuntary.

Accordingly, the Kracht court's rule against the involuntary assignment of legal malpractice claims should apply to only a narrow range of cases. In those cases the Kracht rationale makes sense. Courts should not put the confidentiality of attorney-client relations at risk by exposing them to (truly) involuntary assignments of legal malpractice claims.

This conclusion accords well with previous arguments made on behalf of voluntary assignability. The benefits of allowing the vol-

143268 Cal Rptr at $640 \mathrm{n} 6$.

144 Although in American Employer's Insurance Co. $v$ Medical Protective Co., 165 Mich App 657, 419 NW2d 447 (1988), the court objected that allowing claims to be subrogated would make attorneys less zealous advocates, 419 NW2d at 448-49, its argument mirrors that of the Jackson court, $258 \mathrm{Cal}$ Rptr at 461 , and fails for the same reasons. See text accompanying notes $128-35$.

${ }^{145}$ Even if the estate of a deceased client complains on her behalf, the client herself cannot suffer from having privileged communications aired.

${ }^{148}$ Because clients exchanging malpractice claims for such protection do so consensually, arguments about the advantages of voluntary assignments apply. They may have less strength here, though, since bankrupt clients usually stand in a disadvantaged bargaining position and clients seeking insurance may lack information about the value of the future rights they abandon. 
untary assignment of legal malpractice claims arise from free and open bargaining, which generates prices that honestly reflect the value of legal claims at issue. Coercing clients into handing over their legal malpractice claims would entirely thwart this process.

\section{Conclusion}

This Comment began by asking whether arguments supporting the abandonment of the privity requirement for legal malpractice claims militate in favor of allowing the assignment of such claims. This question arises from a conflict in the way most courts have treated privity and assignment in cases of legal malpractice: they have tended to relax the former while disallowing the latter.

Courts have justified their assault on privity as a means to provide remedies to the victims of legal malpractice, force attorneys to bear the costs of their actions, and deter malpractice in the future. But lowering the privity bar too far has distinctly negative effects on the clarity and certainty of legal malpractice rules. Permitting the voluntary assignment of legal malpractice claims, on the other hand, offers a better means of fulfilling the policy goals that courts lowering the privity bar have tried to achieve. Courts have often overlooked the fact that the same arguments they advance against allowing assignability also apply to relaxing the privity requirement. Worse yet, they have typically failed to give proper credit to the considerable advantages that should follow from the development of a market in legal malpractice claims.

In order to deal with legal malpractice most effectively, courts need to strike a balance between relaxing privity requirements and allowing assignability. Equity and public policy support giving intended beneficiaries legal standing to sue for legal malpractice. But although lowering the privity bar can get courts started on solving the problems of legal malpractice, they should not depend on a change in privity standards to do all the work.

Allowing voluntary assignments of legal malpractice claims may provide courts with a far better means of fulfilling their policy goals. They can correct the minor imperfections of voluntary assignment by guarding against abuse of the market in legal malpractice claims, regulating assignments to former adversaries to avoid "illogical" claims, and prohibiting truly involuntary assignments that violate the confidentiality of attorney-client relations. Apart from these caveats, permitting the voluntary assignment of legal malpractice claims offers considerable advantages. It promises to provide relief to clients of malpracticing attorneys, to force irresponsible attorneys to bear the costs of their actions, to 
deter future malpractice, and generally to increase the equity and efficiency of the legal system. 
